\title{
Influences of Institutional Distance and MNEs' Host Country Experience on the Ownership Strategy in Cross-border M\&As in Emerging Economies
}

\author{
By: \\ Ahmad Arslan * and Desislava Dikova ** \\ * Ahmad Arslan, Senior Lecturer (International Business), Business School, Edge Hill University, \\ Ormskirk, Lancashire, United Kingdom \\ Email: arslana@egehill.ac.uk \\ ** Desislava Dikova, Professor in Institute International Business, \\ Department of Global Business and Trade, Vienna University of Economics \& Business \\ Administration (WU-Wien), Vienna, Austria \\ Email: desislava.dikova@wu.ac.at
}

This is an Accepted Manuscript of an article published by Taylor \& Francis in Journal of Transnational Management on $13^{\text {th }}$ November, 2015 at: http://www.tandfonline.com/doi/full/10.1080/15475778.2015.1093784

Please, cite the paper as:

Arslan, A., \& Dikova, D. (2015). "Influences of Institutional Distance and MNEs' Host Country Experience on the Ownership Strategy in Cross-border M\&As in Emerging Economies”, Journal of Transnational Management, 20:4, 231-256. 


\section{ABTRACT:}

This paper analyzes ownership strategy in cross-border mergers and acquisitions (CB M\&As) undertaken by the multinational enterprises (MNEs) in emerging economies. We use new institutional economics and organizational learning theories to hypothesize and empirically analyze the influence of formal and informal institutional distance, and MNEs' host country experience on the MNEs' choice between full and partial CB M\&As. The empirical analysis is based on a sample of $184 \mathrm{CB}$ M\&As launched by MNEs in emerging economies. Our empirical results revealed that high formal and informal institutional distances lead to a preference for partial CB M\&As however, MNEs' host country experience moderated the relationship between institutional distance and the MNEs' choice between full and partial CB M\&As. We found that MNEs with prior investment experience in the focal emerging market opted for full CB M\&As over partial CB M\&As despite high formal and informal institutional differences.

KEY WORDS: Cross-border M\&As, Full Acquisition, Partial Acquisition, Institutional Distance, MNE Host Country Experience, and Emerging Economies.

\section{INTRODUCTION}

Cross-border mergers and acquisitions (CB M\&As) remain a very popular foreign market entry strategy (Contractor et al. 2014). Unlike the strategic alternative (greenfield) where a foreign subsidiary is set up from scratch over a longer period of time, CB M\&As allow firms to achieve important strategic goals such as speedy entry into a new geographic market or an industry, consolidation of market power in concentrated global industries, firm transformation, taking advantage of a new opportunity or avoiding a possible future threat (Hennart and Park 1993; Collins et al. 2009). Furthermore, through CB M\&As firms procure assets from indigenous firms such as advanced technologies, reputable or locally recognized brands and valuable human resources (Anand and Delios 2002; Chen and Zeng 2004). Hence, it does not come as a surprise that the value and the number of CB M\&As has been on the rise over the years - the total value of CB M\&As in 1990 is registered at $\$ 98.90$ billion while the value in 2012 is reported to be \$308.05 billion (UNCTAD 2013). 
Not all CB M\&As are fully owned by the acquirer despite the obvious advantages of full ownership such as unrestricted access to all the assets of the target firm, the possibility to fully control the strategy of the acquired business and to influence organizational change (Jakobsen and Meyer 2008). MNEs often incur extra costs to manage partially acquired businesses abroad (Chen and Hennart 2004). Considering the obvious downside of partial CB M\&As, here we ask the question what prompts MNEs to choose partial over full CB M\&As? Despite the importance of this issue, ownership decision in CB M\&As is relatively under-researched in comparison to other issues of M\&As such as their valuation (Chari and Chang 2009; Barbopoulos et al. 2012), shareholders' wealth creation (e.g. Harris \& Ravenscraft 1991; Mann and Kohli 2011), postacquisition integration dynamics (e.g. Vaara 2003; Stahl et al. 2012), and post-acquisition performance (e.g. Dikova and Sahib 2013; Chang and Tsai 2013). Only a few studies have studied the circumstances surrounding MNEs' preferences for partial or full acquisitions. Chen and Hennart (2004) for instance found that asymmetric information is one reason for MNEs to reside to partial CB M\&As. Jakobsen and Meyer (2008) on the other hand found that in transition economies MNEs engage in partial acquisitions to gain legitimacy and prevent powerful local stakeholders from hijacking the M\&A deal. Chen (2008) suggested that partial CB M\&As are mostly chosen as a means for capacity control in mature industries and speedy entry into rapidly growing markets. The most recent study by Contractor and colleagues (2014) applies the concept of 'distance' to explain the variation in cross-border acquisition equity levels. We contribute to this relatively unexplored research area by shedding more light on the question what drives MNEs' preferences for partial and full CB M\&As.

The concept of distance has assumed a critical role in international business over the past few decades (Zaheer et al. 2012: 9) and institutional distance in particular has taken a central stage in international business (IB) research (Ingram and Silverman 2002; Estrin et al. 2009). The concept of institutional distance was coined as the extent of dissimilarity (differences) between the national institutions of the home and host country (Kostova 1997). It is found to amplify information asymmetries and uncertainties related to resource transfer and resource acquisition (Chen and Hennart 2004; Dikova et al. 2010). So in the context of CB M\&As, what ownership strategies can MNEs implement to remedy the negative effects of distance? For instance, partial 
acquisitions can be useful in mitigating asymmetric information problems, controlling foreign expansion risk and facilitating the penetration into foreign markets (Zhu and Dutta 2011). Contractor and colleagues (2014) found that minority acquisitions are chosen to reduce uncertainty caused by informal institutional (cultural) distance. Valuable as it is, the latter study indirectly assumes that all acquirers (MNEs) suffer from distance in a similar way. In other words it suggests a direct relationship between distance and ownership stake in CB M\&As thus overlooking a critical boundary condition that limits the effect of distance, the MNEs' local experience in a specific foreign location.

We believe that it is critical to take into consideration the factors that stimulate organizational learning about the local environment. Earlier studies have demonstrated that the possession of market-specific information by the investing firm creates an understanding of the market and its characteristics such as business climate, culture, structure of the market system, and individual customers (Carlsson et al. 2005; Evans et al. 2008). As a consequence, local market experience eliminates factors that prevent MNE's learning about the foreign environment (Dikova 2009). Here we suggest that local market experience reduces information asymmetries and investment risk caused by institutional distance, which in turn moderates the MNE's preference for partial CB M\&A as a way to control investment uncertainties.

The empirical setting of our research is CB M\&As in emerging economies where economic reforms such as privatization and market liberalization have resulted in an increased use of CB M\&As as a form of foreign direct investment: 30 per cent of the total M\&A volume of US\$2.6 trillion in 2012 involved firms located in emerging economies (Thomson Reuters 2013). Our point of interest are CB M\&As launched by Finnish multinationals (MNEs) in emerging economies of Europe, Asia, Latin America and Africa. Acquisitions in emerging economies are complex due to weak legal infrastructure, inefficient bureaucracies, limited law-enforcement, intellectual property protection and market-monitoring mechanisms (Brouthers and Dikova 2010; Schwens et al. 2011; Contractor et al. 2014). Furthermore, different attitudes, beliefs, value systems and behavioral assumptions of individuals and organizations make the cultural characteristics of emerging economies quite different from developed market economies (Contractor et al. 2014). All of these stark differences make the emerging economies not only 
interesting but also suitable context for studying how institutional differences between home and host nations affect the choice between full and partial CB M\&As.

We aspire to making several contributions. First, we further advance existing research by drawing on two particular literature streams - the one dealing with the influence of national institutions on MNEs' strategies (Peng 2003; Peng et al. 2008; Dikova and van Witteloostuijn 2007; Dikova et al. 2010) and the other investigating the role of organizational learning in CB M\&As (Nadolska and Barkema 2007; Dikova et al. 2010). With this approach we offer new insights into the Finnish MNEs acquisitive behavior in institutionally different emerging economies. These insights add to the pool of knowledge concerning the drivers of the MNE preference for partial over full CB M\&As. Second, we point to the importance of location-specific experience for CB M\&As. We suggest that previous experience in the host country can be expected to offset some of the acquisition problems associated with institutional distance. Finally, most of the literature on CB M\&As has focused on studying and explaining acquisition outcomes such as synergies and abnormal returns. We advance our understanding of the key institutional and organizational factors that affect how CB M\&A deals are structured, a topic that has received much less attention especially in the IB research.

\section{THEORY DEVELOPMENT AND HYPOTHESES}

According to North (1990:3), institutions are 'humanly devised constraints that shape human interaction'. Both formal and informal institutions (North 1990) are nation-specific; therefore their ability to reduce uncertainty in human interaction and economic transactions varies across national borders. Moreover, emerging economy institutions differ substantially from developed market economies (Dikova and van Witteloostuijn, 2007), which reduces investing MNEs' ability to fully understand the local rules of the game. As a consequence, MNEs engaging in emerging-economy complex business transactions such as M\&As encounter environmental intricacy and ambiguity that cannot be fully deciphered by drawing on the knowledge of the home-based institutions (Dikova et al., 2010). Moreover, institutional distance further increases

the difficulty and uncertainty surrounding the CB M\&A deal because MNEs adjust more easily to an institutional environment that is similar to their home country (Dikova et al. 2010). 
Organizations accumulate experience through learning how to operate in a specific business environment (March 1991). By building familiarity with the host country, MNEs gradually reduce their perceived level of uncertainty about doing business in the new environment (Meyer and Tran 2006). Reversely, MNEs with relatively limited (or no) experience in a particular market tend to be at a disadvantage due to the lack of knowledge about specific conditions critical for the local operations (Hennart 1991; Hitt and Pisano 2009). Host country specific knowledge is of greater importance for investing MNEs especially in emerging economies (e.g. Uhlenbruck 2004; Demirbag et al. 2008); emerging economies have specific characteristics and peculiar socio-cultural background that sets them apart as a very different business context. MNEs operating in emerging economies face issues ranging from government intervention at strategic level to day-to-day operational hindrances (Demirbag et al., 2008, 2009; Khanna and Palepu 2010). Depending on the level of local knowledge and experience, the risks of acquiring business operations in emerging economies can be substantial (Dikova and van Witteloostuijn, 2007; Arslan and Larimo, 2011). However, ownership strategy is a useful tool in reducing unfamiliarity hazards (Dikova 2009). Shared ownership can reduce the costs associated with liability of foreignness or environmental uncertainty — with superior local knowledge and local connections local partners can assist MNEs in reducing their unfamiliarity with the environment and in enhancing local legitimacy (Gaur and Lu 2007). This is particularly relevant in emerging economies where the ownership of many companies is controlled by a family or a business group and retaining the help of these individuals after the foreign acquisition is of extreme importance especially for MNEs less familiar with the emerging market context (Contractor et al. 2014). We hereby present separate arguments with regard to the role of informal and formal institutional distance and host country experience on the MNEs choice between full or partial M\&A in emerging economies.

\subsection{Formal institutional distance and ownership strategies in cross-border M\&A}

Formal institutions (laws, regulations, political systems, etc.) are different across countries due to differences in historical origins as well as different paces of development of legal structures (e.g. Beck et al. 2003; Arslan and Larimo 2011). CB M\&As are often subject to local regulatory scrutiny induced by bureaucratic self-interest, local political extraction and private benefits such 
as protecting local firms (Bittlingmayer and Hazlett 2000). Moreover, the legal environment of a country influences CB M\&As' takeover premium, as well as the agency costs of transaction and integration of the acquired firm (Barbopoulos et al. 2012).

Due diligence can also be difficult especially in emerging economies because the different regulative structures and accounting standards may can cause problems with evaluation of the target's assets (Dikova et al. 2010). This in turn may either lead to over-paying for the acquired business, or may mislead the investors to over-estimate the possibility to combine the target's assets with the assets of the MNE in a way that creates value for the MNE. Furthermore, the process of acquiring a local firm in an emerging economy can be a slow and difficult due to influence of various stakeholders (Artisien-Maksimenko and Roject 2001; Antal-Mokos 1998). Stakeholders interests can obstruct the M\&A deal completion because often the primary interest of stakeholders in such economies is job-protection rather than profit-maximization (Meyer 2002; Jakobsen and Meyer 2008).

Past studies have noted that in the case of significant regulatory differences between the home and the host countries, the complexity of the CB M\&A deal increases which in turn elevates the uncertainty and risk of the deal (Dikova et al. 2010). Under such circumstances, MNEs investing in CB M\&As in emerging economies may on the one hand prefer to limit their financial exposure by decreasing their equity commitment and pursuing a partial acquisition (Duarte and Garica Canal 2004). On the other hand, by choosing a partial acquisition in a country with very different formal institutional framework, MNEs can rely on the local partner to align their strategic goals with the specific legal requirements of the emerging economy (Meyer 2002). Partial acquisitions provide the possibility to reduce ambiguity (e.g. Eden and Miller 2004) especially because operating under different local rules may create problems with incorporating organizational structures, practices and strategies from the headquarters (Chen and Hennart 2002; Kostova and Roth 2002). Local ownership may ease some of the acquisition hurdles and speed up the negotiation process in emerging economies (Jakobsen and Meyer 2008), especially if the CB M\&A involves restructuring, staff redundancies and job losses (Estrin et al. 2009). Partial acquisition gives an incentive to local owners and managers to render ongoing support to the firm 
since they are well acquainted with local customs, regulations, business networks, and customer preferences (Contractor et al. 2014). Therefore, we hypothesize:

Hypothesis 1a: High formal institutional distance leads to a preference for partial acquisition over full acquisition in emerging economies.

Next, we address the joint effect of formal institutional distance and organizational learning on MNE's choice between full and partial CB M\&As in emerging economies. Emerging economies CB M\&As are plagued by asymmetric information: for example, the potential buyers know less about the value of the target than their owners or stakeholders (Reuer and Koza 2000). This is partially caused by inadequate stock markets and financial systems, which are typical characteristics of emerging economies. The companies for sale in such markets may be 'lemons' yet pre-acquisition inspections can be expensive when the assets of interest for the potential acquirer are tacit technological knowhow or brand-specific goodwill (Harris and Ravenscraft 1991). Full acquisitions also mean the highest resource commitment and capital cost making them more risky and costly (Contractor et al. 2014).

In institutionally distant emerging economies, a MNE without previous experience with the host environment is likely to seek the cooperation of the owners to reduce their motivation to inflate the value of the assets (Chen and Hennart 2004), to avoid prolonging the deal negotiations or incurring additional unforeseen costs. Under such circumstances, locally inexperienced MNEs are unlikely to opt for a full acquisition. However, previous host country specific experience is likely to equip MNEs with knowledge of well performing local players that can be considered as potential (and suitable) targets for an acquisition. Dikova and colleagues (2010) noted that if a MNE engages in a CB M\&A in a country $Y$ then many of the skills necessary to complete that deal would be specific to the particular M\&A deal and country Y. We extend this argument and suggest that business experience in the local environment would generate certain skills and knowledge about the local context that would be beneficial to the MNE engaging in a CB M\&A; in turn the deal uncertainty and risk caused by formal institutional distance are significantly reduced. Full CB M\&A ownership means that the acquirer can enjoy all the future profits of a successful acquisition and the freedom of completely independent decision-making. Therefore, 
we argue that MNEs with host country experience are likely to prefer full acquisition over partial acquisition despite institutional differences as they are better equipped to deal with the local acquisition process and the post-acquisition integration, a direct result of the accumulated knowledge of local business context (Hayward 2002; Zaheer et al. 2013). Based on this discussion, we hypothesize:

Hypothesis 1b: MNEs' host country experience has a positive moderating effect on the relationship between formal institutional distance and CB M\&A ownership strategy: MNEs with previous host country experience acquiring in countries with high formal institutional distance are likely to choose full acquisitions over partial acquisitions.

\subsection{Informal institutional distance and ownership strategies in cross-border M\&A}

Informal institutional distance is caused by differences in norms, values and beliefs between countries (Peng 2003; Estrin et al. 2009; Arslan and Larimo 2011). The knowledge about informal institutions of a country is embedded in the social structures and requires intensive cross cultural understanding by the investing MNEs (North 1990; Peng 2003; Estrin et al. 2009). Organizational structures are part of the firm's administrative heritage which is typically rooted in the national culture (Dikova and van Witteloostuijn 2007). This indicates that post-acquisition integration into the MNE organizational structure might be difficult to administer in culturally distant CB M\&As. Informal institutions also impact different aspects of the foreign subsidiary management such as the ability to understand the aspirations of local employees, and to establish socialization practices and routines for the purpose of knowledge transfer (e.g. Kostova and Roth 2002). The greater the informal institutional distance, the more challenging it would be for the MNE make sense of the local organizational culture, understand and connect with the local employees and ultimately establish a solid base for knowledge exchange. Furthermore, past research has found that the lack of trust in the local management is often a deal-breaker in $\mathrm{CB}$ M\&As (Very and Schweiger 2001; Stahl et al. 2012). Informal institutional differences, often associated with cultural differences, can lead to the use of ambiguous language in the acquisition agreement which in turn can exacerbate the lack of trust between the negotiating parties in a CB 
M\&A, create conflicts and disputes as MNEs seek to finalize the M\&A deal (Dikova et al. 2010) and finally cause delays in the post-acquisition integration process (Bruner 2005).

MNEs investing in emerging economies that are characterized with informal institutional distance would likely benefit from a certain degree of strategic flexibility. We expect that choosing partial acquisitions in such emerging economies can not only offer the advantage of lesser resource commitments to the foreign MNEs (Hill et al. 1990), but also increase the flexibility in strategy and operations for the MNEs (Datta et al. 2009). Past studies have noted that differences in the informal institutional environment are linked to problems associated with information disclosure (e.g. Ali and Hwang 2000). However, when the acquired firm is also a partner in the M\&A (as opposed to being fully acquired and assimilated by the MNE), it can be expected that information disclosure problems for foreign MNEs will be reduced due to the vested interests of the local partner (Duarte and Garcia-Canal 2004). Co-ownership in the CB M\&A also reduces the danger of dramatic organizational changes or a total annihilation of the local organizational culture, thus increasing the willingness of the target-firm management to cooperate. Therefore, we hypothesize that:

Hypothesis 2a: High informal institutional distance leads to a preference for partial acquisition over full acquisition in emerging economies.

Next, we address the joint effect of informal institutional distance and organizational learning on MNE's choice between full and partial CB M\&As in emerging economies. Substantial informal differences can magnify MNE's management perceptions of investment risk and uncertainties and the extent to which home-made routines, procedures, and management practices can be efficiently transferred to and implemented in the new location. Furthermore, such differences may escalate MNE's challenges to successfully establish, monitor and sustain relationships with the local management and various stakeholders, due to differences in attitudes, beliefs, value systems and behavioral assumptions of organizational actors (Contractor et al. 2014). High informal institutional (cultural) distance elevates the level of anxiety and discomfort related to uncertain, unpredictable outcomes and unforeseen costs (Zhao et al. 2004). Hence, in such case, it is likely that MNE's management without host country experience would not engage in an 
outright acquisition but opt for partial acquisition. Moreover, partial acquisitions often offer the flexibility of gaining full acquisition control in subsequent stages.

MNEs engaging in CB M\&As typically have to collect, analyze, distribute and utilize information about the target firm, often under severe time constraints (Very and Schweiger 2001). Familiarity of MNEs with the local context may offset some of the barriers created by cultural (institutional) distance (Gaur and Lu 2007). For example, MNEs with established local operations are likely familiar with nation-specific HR, tax and accounting practices and the local management style (Very and Schweiger 2001). Such experiences enrich the MNE's networks which in turn helps them identify skilled local advisors to assist them with the post-acquisition integration and strategic change (Hayward 2002; Aybar and Facici 2009). Furthermore, accumulated local business experience and established local business networks can help MNEs to better manage professional and cultural differences associated with the management of the acquisition deal (Graebner et al. 2010; Zaheer et al. 2013). In sum, host-country business experience can reduce the uncertainty associated with operating in a culturally distant emerging economy thus reducing the need for retaining a local partner in the focal acquisition. As a result, it is likely that MNEs with significant host country experience are likely to opt for full acquisitions despite the substantial informal institutional differences. We hypothesize the following moderating effect:

Hypothesis 2b: MNEs' host country experience has a positive moderating effect on the relationship between informal institutional distance and CB M\&A ownership strategy: MNEs with previous host country experience acquiring in countries with substantial informal institutional distance are likely to choose full acquisitions over partial acquisitions.

\section{EMPIRICAL RESEARCH DESIGN AND METHODOLOGY}

3.1. Data Sources Description: The main source of data in this study is Finnish FDIs database that has been developed and constantly updated. This internal database of Finnish CB M\&As and FDIs is based on the annual reports of large Finnish firms in the manufacturing sector listed on the Helsinki Stock Exchange and supplemented with the reports from the Finnish business press, 
direct contacts with the investing firms and supplemented with Thomson One Database also. Therefore, we guarantee that our data is reliable, relatively unique and representative of the CB M\&As made in the manufacturing sector by the Finnish MNEs. This database is used for the dependent variable of the study i.e. cross-border full or partial acquisition, as well as for the independent variable MNE's host country experience. Several control variables like industry R\&D intensity, MNEs' size, MNE's international experience, timing of acquisition, and BRICS Dummy are also derived from the same data base.

The institutional indicators for formal-and informal institutional distance in this study are based on yearly data from the World Competitiveness Yearbooks published by The International Institute for Management Development (IMD), Lausanne Switzerland. The World Competitiveness Yearbooks have been used as a reliable and useful resource for analyzing country level institutional environments of different countries in different management and IB studies (e.g. Delios and Beamish, 1999; Gaur et al., 2007; Gaur and Lu, 2007; Arslan and Larimo, 2011). Therefore, selected items from executive surveys of The World Competitiveness Yearbooks are used to measure formal and informal institutional differences between Finland and the host countries (for more information on the specific items please refer to Table 2). Past studies have used alternative data to capture institutional distance such as the World Bank's Governance Indicators as a measure of formal institutions (e.g., Dikova and van Witteloostuijn, 2007; Contractor et al. 2014) and Hofstede's cultural indexes or GLOBE's cultural indexes as a measure of informal institutions (e.g., Aybar and Ficici 2009; Dikova et al. 2010; Contractor et al 2014). We chose a different approach because we believe that rather than general measures, specific indicators of informal institutions that are directly related to market entry and CB M\&As are important to consider.

We use three items from World competitiveness yearbooks including openness to new ideas, corruption, and flexibility and adaptability of people in host economies. Corruption or acceptance of corruption in a society has been referred as an example of informal institutions especially in emerging economies (e.g. Peng et al. 2008; Richey 2010; Tonoyan et al. 2010). We further argue that the society's openness to the foreign ideas captured by national culture item in this study appropriately addresses the attitude to operations of foreign firms in host economies. 
The openness of any society to the foreign ideas (and foreign firms) has been referred as one of the important characteristics of societies that developed and achieved economic competitiveness (e.g. North 1981). Finally, an important aspect of informal institutional environment is flexibility and adaptability of people in a society that influences economic and social behavior as well as competitiveness (de Los Reyes, 2000; Folke et al., 2010). Hence, this indicator is also part of our measure of informal institutional distance.

Following Kogut and Singh (1988) formula for calculating distance, we calculate formal and informal institutional distances.

3.2. Sample Description: We follow the IMF (2013) and Standards and Poor's (S\&P) classification of emerging economies. Our study sample includes acquisitions made in the manufacturing sector by Finnish MNEs in Argentina, Brazil, Bulgaria, China, Colombia, Croatia, Hungary, India, Indonesia, Kazakhstan, Malaysia, Mexico, Peru, Poland, Romania, Russia, South Africa, Thailand, Turkey, Ukraine, Uruguay, and Venezuela during 1990-2008. Since, the transition to market economy started in CEE region in 1990, as well as most Asian, Latin American economies and South Africa opened more for foreign MNE activities and acquisitions during 1990s, the sample time period selection is in line with the study goals. The study sample is rather evenly divided between full (48.9\%) and partial acquisitions (51.1\%). Moreover, we can also observe that most acquisitions were made in low tech (45.1\%) and medium tech (43.5\%) industries, which is expected in the context of emerging economies. Finally, the regional distribution shows the highest number of acquisitions in the CEE region including the Russian Federation (53.4\%), and the lowest in Africa (5.7\%). The main characteristics of our study sample are summarized in table 1.

\section{Insert Table 1 here}

3.3 Variables descriptions and operationalization: The dependent variable of the study is a cross-border acquisition, which is coded 1 for partial acquisitions (94\% or less equity at time of investment) and 0 for full acquisitions (95\% or more equity ownership at time of investment). The equity ownership of $95 \%$ has been used as a cut-off point in our study because most of the 
previous studies analyzing full vs. partial acquisition strategy have categorized equity ownership of $95 \%$ or more at the time of acquisition as full acquisition (e.g. Chen and Hennart 2002, 2004; Jakobsen and Meyer 2008). We performed robustness tests with alternative levels of full ownership (90\% and 100\%). The results remain similar to those reported in the paper. In line with past literature (see table 2), we use a number of control variables at the country, industry and firm level, in order to enhance the validity of the study findings.

\section{Insert Table 2 here}

3.4. Statistical method: The dependent variable in this study is dichotomous (i.e. full vs. partial acquisition); hence, we use binary logistic regression analysis to analyze the impact of the selected variables on the ownership strategy of CB M\&As undertaken by Finnish MNEs. Binary logistic regression has been used often as a reliable statistical analysis technique in past IB studies addressing different aspects of foreign market entry strategies of MNEs (e.g. Hennart and Larimo 1998; Larimo 2003; Dikova and van Witteloostuijn 2007; Demirbag et al. 2008, 2009) as well as acquisition strategy of MNEs specifically (e.g. Arslan and Larimo 2012). Perhaps treating CB M\&A ownership stake as a dichotomous choice is inferior to the approach used by Contractor and colleagues (2014) who consider CB M\&A stake as a choice between minority, majority and full ownership. However, following this approach would require a multinomial regression and unlike logistic regression which offers a clear-cut interpretation of the moderating effects, the interpretation of moderating effects in multinomial regression is not without problems (Greene 2007). Since our aim is to study and explain the moderating effect of MNE experience on the relationship between institutional distance and CB M\&A ownership, we chose the more suitable method, namely logistic regression. The binomial logistic regression model is formally expressed as

$$
P(y i=1)=1 / 1+\exp (-a-X i B)
$$

Where $y i$ is the dependent variable, $X i$ is the vector of independent variables for the ith observation, $a$ is the intercept parameter and $B$ is the vector of regression coefficients (Amemiya, 1981). The recent version of SPSS i.e. PASW 21 is used for the binomial regression analysis in this study. Since the dependent variable has been coded with value 1 for partial acquisition a 
positive regression coefficient indicates that a particular independent variable increases the probability of partial acquisition choice by the investing MNEs.

\section{RESULTS}

The correlation matrix showing pairwise correlations among all the variables of the study is presented in Table 3. The pairwise correlations do not seem to present serious multicollinearity problems for the multivariate analysis, as none of the variables have correlation coefficients above 0.60 (Hair et al. 2013: 227-230). However, following Pallant (2007) we conduct additional multicollinearity diagnostic (tolerance and variance inflation factor (VIF). According to Wetherill (1986), the VIF value should not exceed 10. In the current study, the VIF values of the all the variables are lower than 3 and consequently, the potential collinearity among variables is not expected to influence the results of binomial logistic regression analysis.

\section{Insert Table 3 here}

Table 4 displays the results of our binomial regression analysis. The explanatory power of all the statistical models of the study is good, as their chi-square $\left(\mathrm{x}^{2}\right)$ values are significant at $\mathrm{p} \leq 0.01$ level. Moreover, the predictive capability of the statistical models can be assessed by the correct classification rate. All the models of the study have a higher correct classification rate than the chance rate of $50 \%$, which is calculated using the proportional chance criterion which is $a^{2}+$ $(1-a)^{2}$, where $a$ is a proportion of partial acquisitions $(51.1 \%)$ in the study sample. The regression models show correct classification rates from $73.4 \%$ to $74.5 \%$; this is $23.4 \%$ to $24.5 \%$ improvement in the classification rates of the regression models, which can be considered satisfactory. Moreover, Nagelkerke $\mathrm{R}^{2}(0.281,0.292$ and 0.297$)$ values further show relatively good predictive capability of all three models.

\section{Insert Table 4 here}

Model 1 in table 4 shows the effects of the control variables on the ownership strategy of CB M\&As of Finnish MNEs. The results show that industry R\&D intensity $(p \leq 0.05)$, international 
experience of the investing MNE $(\mathrm{p} \leq 0.1)$, the economic growth in the host country $(\mathrm{p} \leq 0.1)$, the MNE size $(p \leq 0.05)$ and acquisition freedom $(p \leq 0.05)$ are significant control variables. Moreover, the timing of the investment $(p \leq 0.01)$ and the BRICS dummy $(p \leq 0.05)$ are also significant for the ownership strategy in CB M\&As of Finnish MNEs. The regression coefficients depict that high industry $R \& D$ intensity leads to a choice of full acquisition by the investing MNEs. Moreover, the results show that large Finnish MNEs as well as the ones with high international experience preferred full acquisitions over partial acquisitions. The regression results further show that Finnish MNEs preferred full M\&As over partial M\&As in emerging economies that had high acquisition freedom and economic growth indicators at the time of investment. Moreover, the results for the timing variable illustrate that the acquisitions in 1990s were primarily partial acquisitions.

Model 2 in table 4 shows the influence of the independent variables on the ownership stake in CB M\&As of Finnish MNEs in emerging economies. The regression coefficient shows that high formal institutional distance leads to a preference for partial acquisitions by the Finnish MNEs. This renders support to our first hypothesis (1a). The regression results further show that high informal institutional distance leads to a preference for partial acquisitions; this result supports hypothesis $2 \mathrm{a}$ of our study.

Model 3 in table 4 shows the regression output for the interaction terms of formal and informal institutional distances with MNE host country experience. From the main effects of MNE host country experience we infer that Finnish MNEs with high host country experience preferred full acquisitions over partial acquisitions. The regression coefficients of the interaction variables Formal institutional distance X MNE host country experience, and, Informal institutional distance X MNE host country experience are significant and negative indicating a preference for full acquisitions over partial acquisitions. These findings are in line with hypotheses $1 \mathrm{~b}$ and $2 \mathrm{~b}$ of the study. In order to verify the support for the moderating effects, we plot the mean predicted probabilities of partial acquisition choice with high and low ends of formal institutional distance and MNE host country experience as shown in figure 1.

\section{Insert Figure 1 here}


The plot also depicts that the probability of partial CB M\&A choice decreases for MNEs with high host country experience acquiring in countries with high formal institutional distance. We further plot the mean predicted probabilities of partial CB M\&As with high and low ends of informal institutional distance and MNE host country experience, in order to demonstrate the potential moderating influences of host country experience. The plot (figure 2) depicts that the probability of partial CB M\&A decreases for MNEs with high host country experience acquiring in countries with high informal institutional distance.

\section{Insert Figure 2 here}

\section{CONTRIBUTIONS, IMPLICATIONS AND LIMITATIONS}

Our study offers several theoretical, empirical and managerial contributions. The theoretical contribution is specifically linked to the combination of macro and micro level contingencies. Our theory is based on the new institutional economics (e.g. North 1990; Peng 2003; Dikova et al. 2010) and organizational learning literature (e.g. March 1991; Nadolska and Barkema 2007; Zaheer et al. 2013); we developed arguments to explain how institutional distance and local experience affect the preference of MNEs for full or partial CB M\&As. The elevated degree of uncertainty created by institutional distance can be partially offset by reducing the MNE investment risk, i.e. choosing a partial ownership stake at the CB M\&A rather than assuming full CB M\&A ownership. However, local market knowledge may offset the effect of institutional distance because the possession of local market knowledge eliminates factors that prevent MNE's learning about a foreign environment (Dikova 2009). Local market experience reduces information asymmetries and investment risk, which in turn impacts the likely preference for partial CB M\&A as a way to control investment uncertainties caused by institutional distance. This theoretical contribution is especially relevant in the context of emerging economies, where MNEs from advanced economies have the possibility to leverage their resources and skills despite potentially negative influences of institutional distance. Our study leads us to the conclusion that local experience adds to MNEs' skills and capabilities to better analyze the suitability of potential acquisition targets (Aybar and Ficici 2009) and advances their capabilities to manage professional and cultural differences associated with the acquisition management (e.g. 
Zaheer et al. 2013); such MNEs have therefore little benefit in sharing ownership (control and future flow of profits) in the CB M\&A.

Our empirical contribution stems from the relative uniqueness of our dataset, where CB M\&As are undertaken by MNEs from a small, open and highly internationalized (SMOPEC) Nordic economy. IB literature has established that SMOPEC MNEs' internationalization strategies tend to differ from MNEs from large economies like USA, Japan, UK and Germany (e.g. Larimo 2003; Gabrielsson and Gabrielsson 2013). Previous studies analyzing ownership strategy aspects have mostly focused on CB M\&As undertaken by Japanese MNEs (e.g. Chen and Zeng 2004; Chen 2008), CB M\&As undertaken by multiple foreign MNEs in selected transition economies (e.g. Jakobsen and Meyer 2008; Contractor et al 2014) or CB M\&As undertaken by emerging economy MNEs for the purpose of developing new resources and skills (Elango and Pattnaik 2011). Our study offers insights into specific CB M\&A behavior of SMOPEC MNEs in emerging economies, which present attractive growth and market opportunities. The findings of this study have some useful implications for $\mathrm{CB} M \& \mathrm{~A}$ in manufacturing sectors launched in emerging economies. Retaining local ownership can be a useful strategy to overcome institutional differences in emerging economies. However, partial CB M\&As may be costly to manage and coordinate; SMOPEC MNEs with abundant market-specific knowledge, have demonstrated a preference for fully owned CB M\&As. Local knowledge accumulated through doing business in the local economy, can be utilized towards reducing the negative effects of institutional barriers. Locally experienced SMOPEC MNEs tend to utilize their insiders' knowledge of the local emerging economy as this allows them to employ the most suitable strategy in a new dynamic or growing industry, consolidating or maturing industry.

Like all studies, our paper has certain limitations. Firstly, this study only addresses CB M\&As from the perspective of ownership strategy. Therefore, other aspects of CB M\&As (like postacquisition integration, knowledge transfer strategy etc) are not addressed in our paper. Secondly, we treat ownership stake as a dichotomous variable, which reduces the range of possibilities MNEs can choose from when they engage in CB M\&A. Third, the study sample is limited to CB M\&As made by Finnish MNEs in emerging economies. However, in order to increase the generalizability of findings concerning potential moderating influences of host country 
experience on the impacts of formal and informal institutional differences in relation to acquisition strategies, it is recommended for future studies to include other Nordic and SMOPEC economies. Our study also found that ownership strategy in CB M\&As undertaken in BRICS should be distinguished from other emerging economies. As, BRICS represent the largest economies in the group of emerging economies, future studies can analyze if this study results are valid in the case of other emerging economies.

Despite the limitations our paper addresses an important yet under-researched aspect in $\mathrm{CB}$ M\&As, the ownership strategy of the acquiring MNEs. Our study theoretically and empirically established that ownership strategy in CB M\&As is an important decision to consider especially in relation to the influences of institutional distance and MNEs' local experience. Future studies can further explore different aspects of ownership strategy in CB M\&As by analyzing partial acquisitions in depth (i.e. differentiating between minority, 50-50 and majority ownership equity) and how different country, industry and firm level factors influence CB M\&A ownership strategy as well as CB M\&A performance. Such in-depth analysis can further help us solve the key puzzle in M\&A literature i.e. why so many CB M\&As fail, and how CB M\&A performance can be improved. More suitable equity arrangements in certain contexts (e.g. opting for a partial acquisition rather than launching an outright acquisition) may lead to better performance of firms in emerging economies.

\section{REFERENCES}

Ali, A., \& Hwang, L. (2000). Country-specific factors related to financial reporting and the value relevance of accounting data. Journal of Accounting Research, 38(1), 1-21

Amemiya, (1981). Qualitative response models: a survey. Journal of Economic Literature, 19( 4), 1483-1536.

Anand, J., \& Delios, A. (2002). Absolute and relative resources as determinants of international acquisitions. Strategic Management Journal, 23(2), 119-134.

Antal-Mokos, Z. (1998). Privatisation, politics, and economic performance in Hungary. Cambridge University Press.

Arslan, A., \& Larimo, J. (2012). Partial or full acquisition: Influences of institutional pressures on acquisition entry strategy of multinational enterprises. In M. Demirbag and G. Wood (Eds.), 
Handbook of Institutional Approaches to International Business (pp. 320-343). Edward Elgar: UK.

Arslan, A., \& Larimo, J. (2011). Greenfield investments or acquisitions: Impacts of institutional distance on establishment mode choice of multinational enterprises in emerging economies. Journal of Global Marketing, 24(4), 345-356.

Arslan, A., \& Larimo, J. (2010). Ownership strategy of multinational enterprises and the impacts of regulative and normative institutional distance: Evidence from Finnish foreign direct investments in Central and Eastern Europe. Journal of East-West Business, 16(3), 179-200.

Artisien-Maksimenko, P., \& Rojec, M. (2001). Foreign investment and privatization in Eastern Europe: An overview. In P. Artisien-Maksimenko and M. Rojec, (Eds.), Foreign investment and privatization in Eastern Europe. Palgrave: Basingstoke, UK.

Aybar, B., \& Ficici, A. (2009). Cross-border acquisitions and firm value: An analysis of emerging-market multinationals. Journal of International Business Studies, 40(8), 1317-1338.

Barbopoulos, L., Paudyal, K., \& Pescetto, G. (2012). Legal systems and gains from cross-border acquisitions. Journal of Business Research, 65(9), 1301-1312.

Beck, T., Demirguc -Kunt, A., \& Levine, R. (2003). Law and finance: Why does legal origin matter? Journal of Comparative Economics, 31(4), 653-676.

Bittlingmayer, G., \& Hazlett, T. W. (2000). Has antitrust action against Microsoft created value in the computer industry? Journal of Financial Economics, 55(3), 329-359.

Brouthers, K. D., \& Brouthers, L. E. (2001). Explaining the national cultural distance paradox. Journal of International Business Studies, 32(1), 177-189.

Brouthers, K.D. \& Dikova, D. (2010). Acquisitions and real options: The greenfield alternative. Journal of Management Studies, 47(6), 1048-1071.

Bruner, R. (2004). Where M\&A pays and where it strays: A survey of the research. Journal of Applied Corporate Finance, 16(4), 63-76.

Carlsson, J., Nordegren, A. \& Sjoholm, F. (2005). International experience and the performance of Scandinavian firms in China. International Business Review, 14, 21-40.

Chang, S. C., \& Tsai, M. T. (2013). The effect of prior alliance experience on acquisition performance. Applied Economics, 45(6), 765-773.

Chari, M.D.R. \& Chang, K. (2009). Determinants of the share of equity sought in cross-border acquisitions. Journal of International Business Studies, 40 (8), 1277-1297. 
Chen, S. F. (2008). The motives for international acquisitions: capability procurements, strategic considerations, and the role of ownership structures. Journal of International Business Studies, 39 (3), 454-471.

Chen, S. F., \& Zeng, M. (2004). Japanese investors' choice of acquisitions vs. startups in the US: the role of reputation barriers and advertising outlays. International Journal of Research in Marketing, 21(2), 123-136.

Chen, S.F., \& Hennart, J-F. (2004). A hostage theory of joint ventures: why do Japanese investors choose partial over full acquisitions to enter the United States? Journal of Business Research, 57(10), 1126-1134.

Chen, S. F., \& Hennart, J. F. (2002). Japanese investors choice of joint ventures versus whollyowned subsidiaries in the US: The role of market barriers and firm capabilities. Journal of International Business Studies, 33(1), 1-18.

Collins, J. D., Holcomb, T. R., Certo, S. T., Hitt, M. A., \& Lester, R. H. (2009). Learning by doing: Cross-border mergers and acquisitions. Journal of Business Research, 62(12), 1329-1334.

Contractor, F.J., Lahiri, S., Elango, B. \& Kundu, S.K. (2014). Institutional, cultural and industry related determinants of ownership choices in emerging market FDI acquisitions. International Business Review, online first http://dx.doi.org./10.1016/j.ibuserev.2014.02.005.

Datta, D. K., Liang, X., \& Musteen, M. (2009). Strategic orientation and the choice of foreign market entry mode. Management International Review, 49(3), 269-290.

De los Reyes, P. (2000). Diversity at work: paradoxes, possibilities and problems in the Swedish discourse on diversity. Economic and industrial democracy, 21(2), 253-266.

Delios, A., \& Beamish, P. W. (1999). Ownership strategy of Japanese firms: Transactional, institutional and experience influences. Strategic Management Journal, 20(8), 711-727.

Demirbag, M.,Tatoglu E. \& Glaister K.W. (2009). Equity-based entry modes of emerging country multinationals: Lesson from Turkey. Journal of World Business, 44(4), 445-462.

Demirbag, M., Tatoglu, E., \& Glaister, K. W. (2008). Factors affecting perceptions of the choice between acquisition and greenfield entry: The case of Western FDI in an emerging market. Management International Review, 48(1), 5-38.

Dikova, D. (2009). Performance of foreign subsidiaries: Does psychic distance matter? International Business Review, 18(1), 38-49.

Dikova, D., \& Rao Sahib, P. (2013). Is cultural distance a bane or a boon for cross-border acquisition performance? Journal of World Business, 48(1), 77-86. 
Dikova, D., P. R. Sahib \& A. Witteloostuijn (2010) Cross-border acquisition abandonment and completion: The effect of institutional differences and organizational learning in the international business service industry, 1981-2001. Journal of International Business Studies, 41(2), 223-245

Dikova, D., \& Van Witteloostuijn, A. (2007). Foreign direct investment mode choice: entry and establishment modes in transition economies. Journal of International Business Studies, 38(6), 1013-1033.

Dow, D. \& Larimo, J. (2009). Challenging the conceptualization and measurement of distance and international experience in entry mode choice research. Journal of International Marketing ,17 (2), 74-98.

Duarte, C. L., \& García-Canal, E. (2004). The choice between joint ventures and acquisitions in foreign direct investments: The role of partial acquisitions and accrued experience. Thunderbird International Business Review, 46(1), 39-58.

Eden, L. \& Miller, S. (2004). Distance matters: Liability of foreignness, institutional distance and ownership strategy. In M. Hitt \& J. Cheng (Eds.). Theories of the Multinational Enterprise Diversity, Complexity and Relevance Advances in International Management Vol 16 (pp.187221). Elsevier: New York, NY.

Elango, B., \& Pattnaik, C. (2011). Learning before making the big leap, Management International Review, 51(4), 461-481.

Estrin, S., Baghdasaryan, D., \& Meyer, K. E. (2009). The impact of institutional and human resource distance on international entry strategies. Journal of Management Studies, 46(7), 11711196.

Evans, J., Mavondo, F.T. \& Bridson, K. (2008) Psychic distance: Antecedents, retail strategy implications, and performance outcomes. Journal of International Marketing, 16(2), 32-63.

Folke, C., Carpenter, S. R., Walker, B., Scheffer, M., Chapin, T., \& Rockström, J. (2010). Resilience thinking: integrating resilience, adaptability and transformability. Ecology and Society, 15(4), 20.

Gabrielsson, P., \& Gabrielsson, M. (2013). A dynamic model of growth phases and survival in international business-to-business new ventures: The moderating effect of decision-making logic. Industrial Marketing Management, 42(8), 1357-1373.

Gaur, A.S. \& Lu, .W. (2007). Ownership strategies and survival of foreign subsidiaries: Impacts of institutional distance and experience. Journal of Management, 33(1), 84-110.

Graebner, M. E., Eisenhardt, K. M., \& Roundy, P. T. (2010). Success and failure in technology acquisitions: Lessons for buyers and sellers. The Academy of Management Perspectives, 24(3), 73-92.

Greene, W. H. (2007), Econometric Analysis (6th ed.). Upper Saddle River, New Jersey: Prentice Hall. 
Gwartney, J., Lawson, R., \& Norton, S. (2008). Economic freedom of the world 2008 annual report. The Fraser Institute: BC, Canada.

Hair, J.F. Jr., Anderson, R.E., Tatham, R.L., \& Black, W.C. (2013). Multivariate Data Analysis. $7^{\text {th }}$ Edition. Prentice Hall: Upper Saddle River, NJ.

Harris, R. S., \& Ravenscraft, D. (1991). The role of acquisitions in foreign direct investment: Evidence from the US stock market. The Journal of Finance, 46(3), 825-844.

Hayward, M. L. (2002). When do firms learn from their acquisition experience? Evidence from 1990 to 1995. Strategic Management Journal, 23(1), 21-39.

Hennart, J.F. (1991). A Transaction Costs Theory of Equity Joint Ventures: An Empirical Study of Japanese Subsidiaries in the United States. Strategic Management Journal, 9(4), 361-374.

Hennart, J. F., \& Park, Y. R. (1993). Greenfield vs. acquisition: The strategy of Japanese investors in the United States. Management science, 39(9), 1054-1070.

Hennart, J. F., \& Larimo, J. (1998). The impact of culture on the strategy of multinational enterprises: does national origin affect ownership decisions? Journal of International Business Studies, 29(3), 515-538.

Hill, C. L., Hwang, P., \& Kim, W. C. (1990). An eclectic theory of the choice of international entry mode. Strategic Management Journal, 11(2), 117-128.

Hitt and Pisano (2009). Cross border mergers and acquisitions: Challenges and opportunities. In Pablo, A. L., \& Javidan, M. (Eds.). (2009). Mergers and acquisitions: Creating integrative knowledge (pp. 45-59). Oxford, UK: Wiley Blackwell.

IMD (2010). World Competitiveness Yearbooks. Lausanne: Switzerland.

IMF (2013). International Monetary Fund Rating of Emerging Economies. Retrieved from www.imf.org.

Ingram, P. \& Silverman, B.S. (2002). Introduction: The new institutionalism in strategic management, in Paul Ingram and Brian S. Silverman (ed.) The New Institutionalism in Strategic Management (Advances in Strategic Management, Volume 19), Emerald Group Publishing Limited, 1-30.

Jakobsen, K. \& Meyer, K. E. (2008). Partial acquisitions: the overlooked entry mode. In J. H. Dunning and Gugler P. (eds). Process in International Business Research 2 (pp. 2013-226.). New York: Oxford University Press Inc.

Kogut, B. \& Singh, H. (1988). The effect of national culture on the choice of entry mode. Journal of International Business Studies, 19(3), 411-432. 
Kostova, T. (1997). Country institutional profile: Concept and measurements. Academy of Management Proceedings, 1, 180-184.

Kostova, T., \& Roth, K. (2002). Adoption of an organizational practice by subsidiaries of multinational corporations: Institutional and relational effects. Academy of Management Journal, 45(1), 215-233.

Khanna, T., \& Palepu, K. G. (2010). Winning in emerging markets: A road map for strategy and execution. Harvard Business Press: Harvard, MT.

Larimo, J. (2003). Form of investment by Nordic firms in world markets. Journal of Business Research, 56(10), 791-803.

Larimo, J., \& Arslan, A. (2013). Determinants of foreign direct investment ownership mode choice: Evidence from Nordic investments in Central and Eastern Europe. Journal for East European Management Studies, 18(2), 232-263.

Mann, B. J. S., \& Kohli, R. (2011). Target shareholders' wealth creation in domestic and crossborder acquisitions in India. International Journal of Commerce and Management, 21(1), 63-81.

March, J. G. (1991). Exploration and exploitation in organizational learning. Organization Science, 2(1), 71-87.

Meyer, K. E. (2001). Institutions, transaction costs and entry mode choice in Eastern Europe. Journal of International Business Studies, 31(2), 357-367.

Meyer, K. E. (2002). Management challenges in privatization acquisitions in transition economies. Journal of World Business, 37(4), 266-276.

Meyer, K.E., \& Tran, Y.T.T. (2006). Market penetration and acquisition strategies for emerging economies, Long Range Planning, 39(2), 177-197.

Nadolska, A., \& Barkema, H. G. (2007). Learning to internationalize: the pace and success of foreign acquisitions. Journal of International Business Studies, 38(7), 1170-1186.

North, D. C. (1981). Structure and Change in Economic History. New York: Norton.

North, D. C. (1990). Institutions, institutional change and economic performance. Cambridge University press.

Padmanabhan, P., \& Cho, K. R. (1999). Decision specific experience in foreign ownership and establishment strategies: Evidence from Japanese firms. Journal of International Business Studies, 30(1), 25-43.

Pallant, J. (2007). SPSS survival manual: a step by step guide to data analysis using SPSS for windows. Buckingham: Open University Press. 
Peng, M. W (2003), Institutional transitions and strategic choices, Academy of Management Review, 28(2), 275-296.

Peng, M, Wang, D., \& Jiang, Y. (2008). An Institution-based view of international business strategy: A focus on emerging economies. Journal of International Business Studies, 39(5), 920936.

Reuer, J \& Koza, M. (2000). Asymmetric information and joint venture performance: theory and evidence for domestic and international joint ventures. Strategic Management Journal, 21(1), 8088.

Richey, S. (2010). The impact of corruption on social trust. American Politics Research, 38((4), 676-690.

Schneper, W. D., \& Guillén, M. F. (2004). Stakeholder Rights and Corporate Governance: A Cross-National Study of Hostile Takeovers. Administrative Science Quarterly, 49(2), 263-295.

Schwens C., Eiche J., \& Kabst R. (2011). The moderating impact of informal institutional distance and formal institutional risk on SME entry mode choice. Journal of Management Studies, 48(2), 330-351.

Shaver, J., \& Flyer, F. (2000). Agglomeration economies, firm heterogeneity, and foreign direct investment in the United States. Strategic Management Journal, 21(12), 1175-1193.

Shaver J., Mitchell W., Yeung B. (1997). The effect of own-firm and other-firm experience on foreign direct investment survival in the United States, 1987-92. Strategic Management Journal, $18(10), 811-824$

Stahl, G. K., \& Chua, C. H. (2012). Does national context affect target firm employees' trust in acquisitions? .Management International Review, 52(3), 395-423.

Thomson Reuters (2013). Mergers \& Acquisitions Review. Retrieved from http://dmi.thomsonreuters.com/Content/Files/Q12013_MA_Global_FA_Review.pdf.

Tonoyan, V., Strohmeyer, R., Habib, M., \& Perlitz, M. (2010). Corruption and entrepreneurship: How formal and informal institutions shape small firm behavior in transition and mature market economies. Entrepreneurship Theory and Practice, 34(5), 803-831.

Uhlenbruck, K. (2004). Developing acquired foreign subsidiaries: The experience of MNEs in transition economies. Journal of International Business Studies, 35(2), 109-123.

UNCTAD (2013). Value of cross-border M\&A by region/economy of seller, 1990-2012. Geneva, United Nations.

Vaara, E. (2003). Post-acquisition integration as sense making: Glimpses of ambiguity, confusion, hypocrisy, and politicization. Journal of Management Studies, 40(4), 859-894. 
Very, P., \& Schweiger, D. M. (2001). The acquisition process as a learning process: Evidence from a study of critical problems and solutions in domestic and cross-border deals. Journal of World Business, 36(1), 11-31.

Wetherill, G.B. (1986). Regression Analysis with Applications. London: Chapman and Hall.

Zaheer, S., Schomaker, M. S., \& Nachum, L. (2012). Distance without direction: Restoring credibility to a much-loved construct. Journal of International Business Studies, 43(1), 18-27.

Zaheer, A., Castañer, X., \& Souder, D. (2013). Synergy sources, target autonomy, and integration in acquisitions. Journal of Management, 39(3), 604-632.

Zhao, H., Luo, Y., \& Suh, T. (2004). Transaction cost determinants and ownership-based entry mode choice: A meta-analytical review. Journal of international business studies, 35(6), 524-544.

Zhu, P. \& Dutta, S. (2011). Partial acquisition: Motivation and consequences on firm performance. In Baker, H.K. \& Kiymaz, H. (eds.), The art of capital restructuring: Creating shareholder value through mergers and acquisitions. John Wiley \& Sons, Inc., Hoboken, New Jersey. 
Table 1: Sample Characteristics

\begin{tabular}{|l|l|}
\hline Sample Characteristic & Description \\
\hline Cross-border acquisition & 90 full acquisitions (48.9\%); 94 partial acquisitions (51.1\%) \\
\hline $\begin{array}{l}\text { Host Country Experience of } \\
\text { Investing Firms }\end{array}$ & $\begin{array}{l}\text { Average: 3.39 years. Minimum: 0 years (No earlier experience in the host country; } \\
\text { All entries with no previous experience are included in analysis). Maximum: } 31 \\
\text { years. }\end{array}$ \\
\hline $\begin{array}{l}\text { Number of acquisitions in } \\
\text { particular time period }\end{array}$ & $1990-1999: 82(44.6 \%) ; 2000-2009: 102(55.4 \%)$ \\
\hline $\begin{array}{l}\text { R\&D intensity of investing } \\
\text { firms }\end{array}$ & Low-Tech (83; 45.1\%); Medium Tech (80; 43.5\%); High-Tech (21; 11.4\%) \\
\hline $\begin{array}{l}\text { Major Acquisition } \\
\text { Destinations }\end{array}$ & Asia (48; 24.9\%), CEE including Russia (96; 53.4\%), Others (40; 21.7\%) \\
\hline
\end{tabular}


Table 2. Operationalization of study variables

\begin{tabular}{|c|c|c|}
\hline VARIABLES & OPERATIONALIZATION & REFERENCE(S) \\
\hline 1. CB M\&A & $\begin{array}{l}0=\text { full acquisition (95\% or more equity), } 1=\text { partial acquisition (less } \\
\text { than } 95 \% \text { equity) }\end{array}$ & $\begin{array}{l}\text { Chen and Hennart (2002, } \\
\text { 2004); Jakobsen and Meyer } \\
(2008)\end{array}$ \\
\hline $\begin{array}{l}\text { 2. Formal } \\
\text { institutional distance }\end{array}$ & $\begin{array}{l}\text { The difference between Finland and host country in the year of } \\
\text { investment / scores in nearest available year. (Source: World } \\
\text { Competitiveness Yearbooks) } \\
\text { 1. Competition legislation is preventing unfair competition (from 1- } \\
\text { 10) } \\
\text { 2. Adaptability of government policy to changes in the economy is } \\
\text { high (from 1-10) } \\
\text { 3. Transparency of government policy is satisfactory (from 1-10) }\end{array}$ & Arslan and Larimo (2011) \\
\hline $\begin{array}{l}\text { 3. Informal } \\
\text { institutional distance }\end{array}$ & $\begin{array}{l}\text { The difference between Finland and host country in the year of } \\
\text { investment / scores in nearest available year. (Source: World } \\
\text { Competitiveness Yearbooks) } \\
\text { 1. National Culture is open to foreign ideas (from 1-10) } \\
\text { 2. Bribing and Corruption do not exist (from 1-10) } \\
\text { 3. Flexibility and adaptability of people are high (from 1-10) }\end{array}$ & Arslan and Larimo (2011) \\
\hline $\begin{array}{l}4 \text { Host country } \\
\text { experience of the } \\
\text { investing MNE }\end{array}$ & $\begin{array}{l}\text { The experience in years from the first manufacturing investment of } \\
\text { the firm in the host country }\end{array}$ & $\begin{array}{l}\text { Hennart \& Park (1993); } \\
\text { Padmanabhan \& Cho (1999); } \\
\text { Larimo (2003); Arslan and } \\
\text { Larimo (2011, 2012) }\end{array}$ \\
\hline $\begin{array}{l}\text { 5. Industry R\&D } \\
\text { intensity }\end{array}$ & $\begin{array}{l}\text { A classification of various 4-digit SIC industries into three } \\
\text { categories (Low-Tech, Medium-Tech and High-Tech) based on their } \\
\text { value added figures }\end{array}$ & $\begin{array}{l}\text { Larimo (2003); Dikova \& } \\
\text { Witteloostuijn (2007) }\end{array}$ \\
\hline 6. MNE size & $\begin{array}{l}\text { Natural Log of Global sales of the parent MNE in the year preceding } \\
\text { to investment changed to Euros }\end{array}$ & $\begin{array}{l}\text { Hennart \& Park (1993); Dow } \\
\text { \& Larimo (2009). }\end{array}$ \\
\hline $\begin{array}{l}\text { 7. International } \\
\text { experience of the } \\
\text { investing MNE }\end{array}$ & $\begin{array}{l}\text { The experience in years from the first manufacturing investment of } \\
\text { the MNE abroad }\end{array}$ & $\begin{array}{l}\text { Shaver et al. (1997); Shaver } \\
\text { \& Flyer (2000) }\end{array}$ \\
\hline $\begin{array}{l}\text { 8. Economic growth } \\
\text { in the host country }\end{array}$ & $\begin{array}{l}\text { Economic growth (\% of GDP growth) in the host country in the year } \\
\text { preceding to year when CB M\&A is undertaken }\end{array}$ & $\begin{array}{l}\text { Hennart (1991); Brouthers \& } \\
\text { Brouthers (2001); Arslan and } \\
\text { Larimo (2010 2011, 2012) }\end{array}$ \\
\hline 9. Host country risk & $\begin{array}{l}\text { The host country risk in the year preceding the investment based on } \\
\text { Euro money country risk ratings }\end{array}$ & $\begin{array}{l}\text { Larimo (2003); Demirbag et } \\
\text { al. (2009) }\end{array}$ \\
\hline $\begin{array}{l}\text { 10. Ownership } \\
\text { Freedom in the host } \\
\text { country }\end{array}$ & $\begin{array}{l}\text { Country score in item ownership restrictions (Scores from 1-10; } \\
\text { where } 10 \text { shows least restricted economies) from Economic Freedom } \\
\text { of the World annual reports }\end{array}$ & Gwartney et al. (2008) \\
\hline $\begin{array}{l}\text { 12. Acquisition } \\
\text { freedom in the host } \\
\text { country }\end{array}$ & $\begin{array}{l}\text { Country scores in the item: Foreign Investors are free to acquire } \\
\text { control in local firms (Scores from 1-10) from World } \\
\text { Competitiveness Yearbooks }\end{array}$ & Larimo \& Arslan (2013 \\
\hline $\begin{array}{l}\text { 11. Timing of M\&A } \\
\text { dummy }\end{array}$ & 1 stands for CB M\&As in 1990s and 0 for M\&As in 2000s & Peng (2003) \\
\hline 12. BRICS Dummy & $\begin{array}{l}1 \text { stands for M\&As made in large economies of BRICS (Brazil, } \\
\text { Russia, India, China \& South Africa) and } 0 \text { for M\&As in other } \\
\text { countries }\end{array}$ & - \\
\hline
\end{tabular}


Table 3: Descriptive Statistics and Pearson Correlations

\begin{tabular}{|c|c|c|c|c|c|c|c|c|c|c|c|c|c|c|c|}
\hline & Mean & Std.dev & 1. & 2. & 3. & 4. & 5. & 6. & 7. & 8. & 9. & 10. & 11. & 12. & 13. \\
\hline $\begin{array}{l}\text { 1. Cross-border } \\
\text { acquisition }\end{array}$ & 0.51 & 0.501 & 1 & & & & & & & & & & & & \\
\hline $\begin{array}{l}\text { 2. Industry R\&D } \\
\text { Intensity }\end{array}$ & 1.66 & 0.674 & -0.086 & 1 & & & & & & & & & & & \\
\hline $\begin{array}{l}\text { 3. MNE international } \\
\text { experience }\end{array}$ & 38.26 & 26.535 & 0.001 & -0.077 & 1 & & & & & & & & & & \\
\hline 4. Economic growth & 4.163 & 5.324 & -0.128 & 0.053 & $0.190^{*}$ & 1 & & & & & & & & & \\
\hline 5. Host country risk & 53.89 & 12.67 & -0.156 & 0.119 & 0.135 & $0.553^{*}$ & 1 & & & & & & & & \\
\hline 6. MNE size & 6.927 & 1.446 & -0.029 & 0.044 & 0.475 & 0.170 & 0.137 & 1 & & & & & & & \\
\hline 7. Ownership freedom & 6.279 & 1.451 & -0.007 & 0.142 & 0.064 & -0.066 & $0.206 *$ & 0.035 & 1 & & & & & & \\
\hline 8. Acquisition freedom & 6.225 & 1.688 & -0.095 & 0.129 & 0.004 & -0.048 & $0.221 *$ & -0.027 & 0.588 & 1 & & & & & \\
\hline 9. Timing & 0.45 & 0.498 & $0.265^{*}$ & -0.039 & -0.120 & $-0.417 *$ & $-0.217 *$ & -0.154 & 0.161 & $0.210^{*}$ & 1 & & & & \\
\hline 10. BRICS & 0.49 & 0.501 & -0.054 & -0.070 & 0.079 & 0.026 & $-0.244 *$ & 0.104 & $-0.564 *$ & $-0.451^{*}$ & -0.187 & 1 & & & \\
\hline $\begin{array}{l}\text { 11. Formal institutional } \\
\text { distance }\end{array}$ & 3.469 & 0.760 & 0.050 & -0.120 & -0.015 & $-0.397 *$ & $-0.481 *$ & -0.003 & $-0.305 *$ & $-0.236 *$ & 0.092 & $0.237 *$ & 1 & & \\
\hline $\begin{array}{l}\text { 12. Informal institutional } \\
\text { distance }\end{array}$ & 3.302 & 0.812 & 0.116 & -0.043 & -0.166 & $-0.214^{*}$ & $-0.284 *$ & -0.054 & -0.183 & -0.109 & 0.109 & -0.037 & $0.447 *$ & 1 & \\
\hline $\begin{array}{l}\text { 13. MNE host country } \\
\text { experience }\end{array}$ & 3.52 & 5.470 & -0.032 & 0.112 & $0.308^{*}$ & 0.153 & 0.017 & $0.245^{*}$ & -0.148 & -0.149 & -0.262 & $0.246^{*}$ & 0.029 & -0.058 & 1 \\
\hline
\end{tabular}

* Correlation is significant at the $\mathrm{p} \leq 0.01$ level (2-tailed). 
Table 4: Binomial logistic regression estimates (partial acquisition $=1$ )

\begin{tabular}{|c|c|c|c|}
\hline Variable & $\begin{array}{l}\text { Model 1: Control } \\
\text { Variables }\end{array}$ & $\begin{array}{l}\text { Model 2: Independent } \\
\text { Variables }\end{array}$ & $\begin{array}{c}\text { Model 3: Moderating } \\
\text { Influences }\end{array}$ \\
\hline Industry R\&D intensity & $-0.181 * *$ & $-0.230 * *$ & $-0194 * *$ \\
\hline International experience of MNE & $-0.470^{*}$ & $-0.493 *$ & $-0.485^{*}$ \\
\hline Economic growth in host country & $-0.132 *$ & $-0.11^{*}$ & $-0.067 *$ \\
\hline Host country risk & -0.020 & -0.019 & 0.017 \\
\hline MNE size & $-0.132 * *$ & $0.094 *$ & $-0.132 * *$ \\
\hline Ownership freedom & 0.179 & 0.198 & 0.163 \\
\hline Acquisition freedom & $-0.340 * *$ & $-0.356 * *$ & $-0.348 * *$ \\
\hline Timing of acquisition & $1.270 * * *$ & $1.301 * * *$ & $1.304 * * *$ \\
\hline BRICS dummy & $0.352 * *$ & $0.391 * *$ & $0.426 * *$ \\
\hline Formal institutional distance & & $0.868 * *$ & \\
\hline Informal institutional distance & & $0.932 * *$ & \\
\hline MNE host country experience & & $-0.340 * * *$ & \\
\hline $\begin{array}{c}\text { Formal institutional distance X MNE } \\
\text { host country experience }\end{array}$ & & & $-0.708 * *$ \\
\hline $\begin{array}{c}\text { Informal institutional distance X MNE } \\
\text { host country experience }\end{array}$ & & & $-0.178 * *$ \\
\hline$N$ (Partial acquisitions) & 184(94) & 184(94) & 184(94) \\
\hline Model $x^{2}$ & $43.504 * * *$ & $44.709 * * *$ & $48.705 * * *$ \\
\hline-2 log likelihood & 211.488 & 210.282 & 206.286 \\
\hline Nagelkerke $R^{2}$ & 0.281 & 0.288 & 0.310 \\
\hline Correctly classified (\%) & $73.4 \%$ & $74.3 \%$ & $74.5 \%$ \\
\hline
\end{tabular}

Levels of Significance: ${ }^{*} \mathrm{p} \leq 0.1,{ }^{* *} \mathrm{p} \leq 0.05,{ }^{* * *} \mathrm{p} \leq 0.01$ 
Figure 1: Interaction plot of formal institutional distance and MNE host country experience for cross-border acquisitions of Finnish MNEs

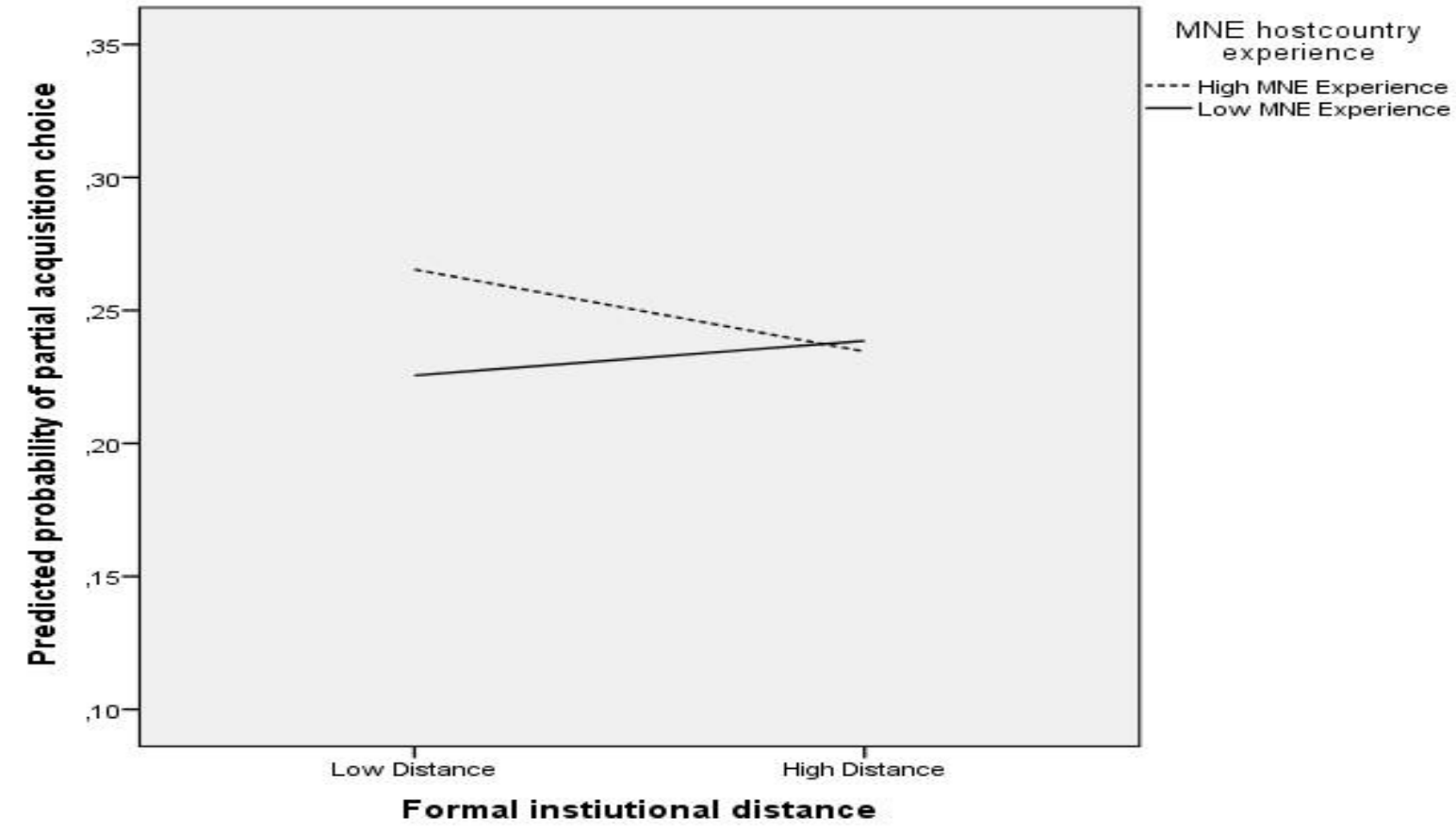

Figure 2: Interaction plot of informal institutional distance and MNE host country experience for cross-border acquisitions of Finnish MNEs

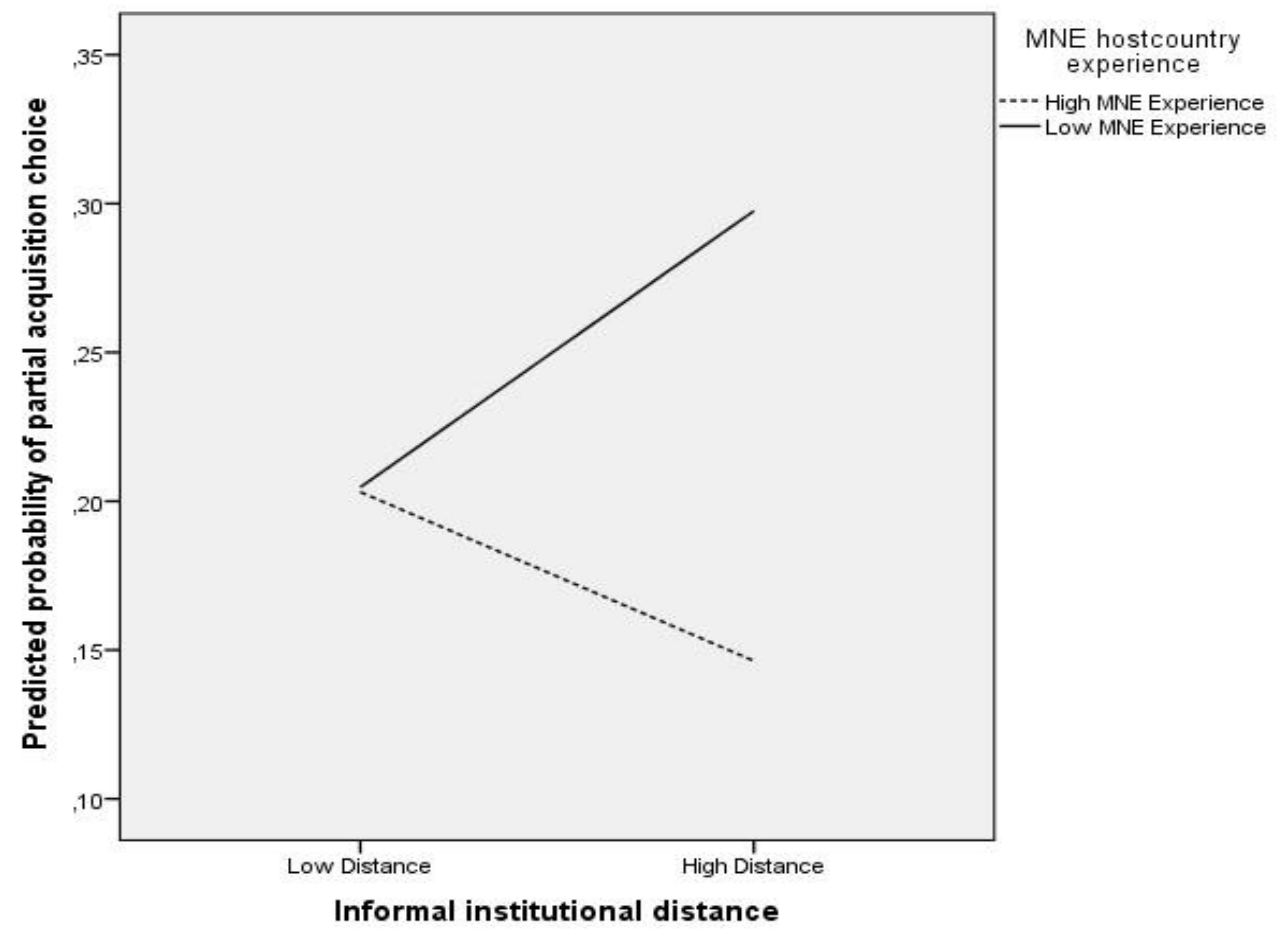

